\title{
43. CHALK SOLUTION STRUCTURES IN CORES FROM DEEP SEA DRILLING PROJECT LEG 941
}

\author{
Philip R. Hill, Geological Survey of Canada ${ }^{2}$
}

\begin{abstract}
Solution structures in the lithologic sections recovered from DSDP Holes 608 and 610 consist of four types: (1) dispersed solution fabric, (2) wispy solution seams, (3) flaser chalks, (4) marl seams. Gradations in the degree of dissolution and consequent texture were observed both in hand specimens and on a microscopic scale. The solution zones are characterized by a decrease in grain size, a relative abundance of siliceous organisms, and a relatively high concentration of clay minerals, although the zones retain a mainly carbonate composition. The solution structures are associated with zones of faulting and tilting. They correspond to a diffuse zone of discontinuous seismic reflectors at Site 610 . Similar associations can be seen at previously drilled DSDP sites where solution structures have been observed, and in Cretaceous chalks of the Isle of Wight (U.K.). The structures are associated with fault and joint patterns which indicate stretching of the chalk beds between solution zones. It is suggested that the distribution of solution structures is controlled by stresses related to differential compaction. Oozes and chalks exhibit granular (silt-like) behavior during mechanical deformation, and pressure solution is both enhanced and subsequently inhibited by changes in pore fluid pressure under undrained conditions. Thus, individual solution seams are very thin but converge as a result of lateral dislocation along the seams.
\end{abstract}

\section{INTRODUCTION}

During Shipboard visual examination of cores from Holes 608 and 610 on DSDP Leg 94, post-depositional sedimentary structures initially described as "wispy solution laminae" were noted in the more consolidated chalky parts of the cores (see site reports, this volume). Some structures are identical to "flaser chalk" structures from the Cretaceous Chalk of southern England, described by Garrison and Kennedy (1977). The presence, in Holes 608 and 610, of solution structures at important horizons associated with possible hiatuses and corresponding to regional reflectors, warranted further investigation of the nature and origin of the flaser chalk lithology. In this chapter, the structures are described in detail, compared with other examples in European chalk sequences, and interpreted in the light of their structural and stratigraphic settings.

\section{METHODS}

Examples of the structures were photographed during shipboard examination of the cores. Eight vertical slab samples were subsequently cut from the split core faces, and polished thin sections were made with the same vertical orientation. The thin sections were examined under plane polarized light. Small blocks from the slabs with vertical broken faces oriented at $90^{\circ}$ to the plane of thin section were mounted on scanning electron microscope stubs and coated with carbon. These samples were examined and photographed in a Cambridge Model 180 scanning electron microscope (SEM). An Ortec energy-dispersive analyzer was used for spot analyses of the samples in the SEM, and provided a rapid method to distinguish fine carbonate and clay particles.

\section{DESCRIPTION}

On a macroscopic scale, the flaser structures are associated with the more marly intervals in the chalk se-

\footnotetext{
${ }^{1}$ Ruddiman, W. F., Kidd, R. B., Thomas, E. et al., Init. Repts. DSDP, 94: Washington (U.S, Govt. Printing Office)

2 Address: Geological Survey of Canada, Atlantic Geoscience Centre, Bedford Institute of Oceanography, P.O. Box 1006, Dartmouth, N.S., B2Y 4A2, Canada.
}

quence. A range of gradational structures is included here in the term flaser structure.

1. A dispersed solution fabric shows the least development of solution features, and is characterized by a barely perceptible darkening of the chalk, recognized as an incipient "wispy" foliation (Fig. 1A). There is no development of discrete solution laminae on the macroscopic scale.

2. Wispy solution seams occur as isolated or clustered laminae, generally subparallel to bedding, although they may substantially cut across bedding (Fig. 1B). The laminae often show complex anastomosing patterns in vertical sections, enclosing very thin lozenge-shaped inclusions of white chalk. Several solution seams may converge to form flaser chalk or thicker green marly laminae.

3. Flaser chalks consist essentially of large numbers of anastomosing wispy laminae, which completely pervade the chalk lithology to give the characteristic flaser appearance (Fig. 1C). The intervening chalk lenses vary in size from a few millimeters to much less than a millimeter, and are characteristically tapered in the horizontal plane.

4. Marl seams result from convergence of numerous solution laminae to form a distinctive dark green marly bed (Figs. 1D, E) about $1 \mathrm{~cm}$ thick. These seams therefore appear to represent an advanced stage among the successive stages of solution just described. Well-developed seams are always oriented parallel to bedding (Fig. 1D), but they may exhibit an additional subhorizontal solution fabric (Fig. 1E).

In thin section, the same gradation in the degrees of dissolution can be seen (Fig. 2). The unaffected chalk has a fine-grained texture and contains a large number of fresh-looking foraminifer tests, whole and fragmented (Fig. 2A). The initial stage of dissolution is characterized by discontinuous flecks of finer-grained sediment 

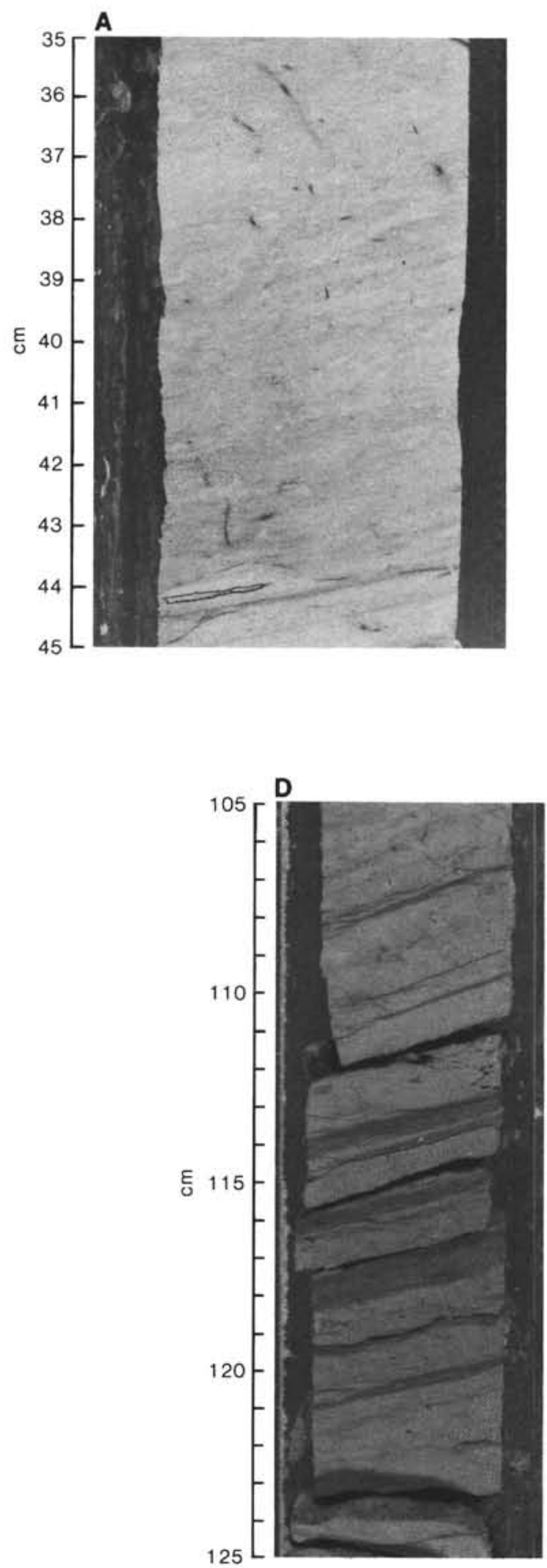
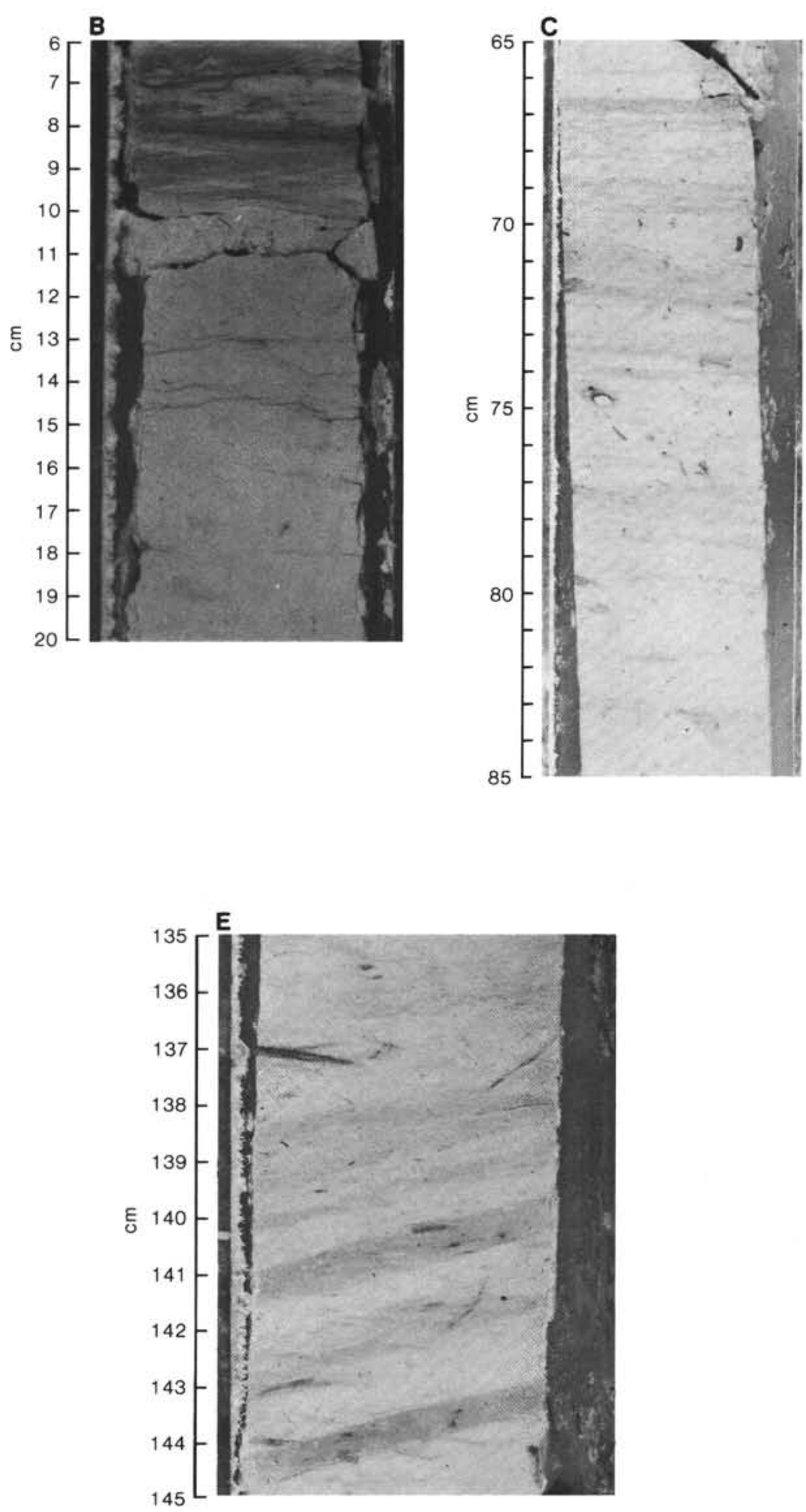

Figure 1. Examples of solution structures from Leg 94 . A. Dispersed solution fabric $(610-23-1,35-45 \mathrm{~cm})$. B. Wispy solution seams $(610-16-4,6-20$ $\mathrm{cm})$. C. Flaser chalk $(610-25-2,65-85 \mathrm{~cm})$. D. Marl seams $(610-25-3,105-125 \mathrm{~cm})$. E. Horizontal solution fabric cross-cutting dipping marl seams $(610-25-1,135-145 \mathrm{~cm})$.

(darker in Fig. 2B). In the vicinity of the foraminifer tests, broader fine-grained zones are sometimes present (Fig. 2B). The tests are generally truncated along a subhorizontal plane (Fig. 2C), indicating preferential dissolution of the foraminifers.
At a more advanced stage of solution, the solution features are clearly seen as very thin, fine-grained zones showing an anastomosing pattern on the finer scale similar to that on the hand-specimen scale (Fig. 2C). Foraminifer tests are observed only in the chalk lenses be- 

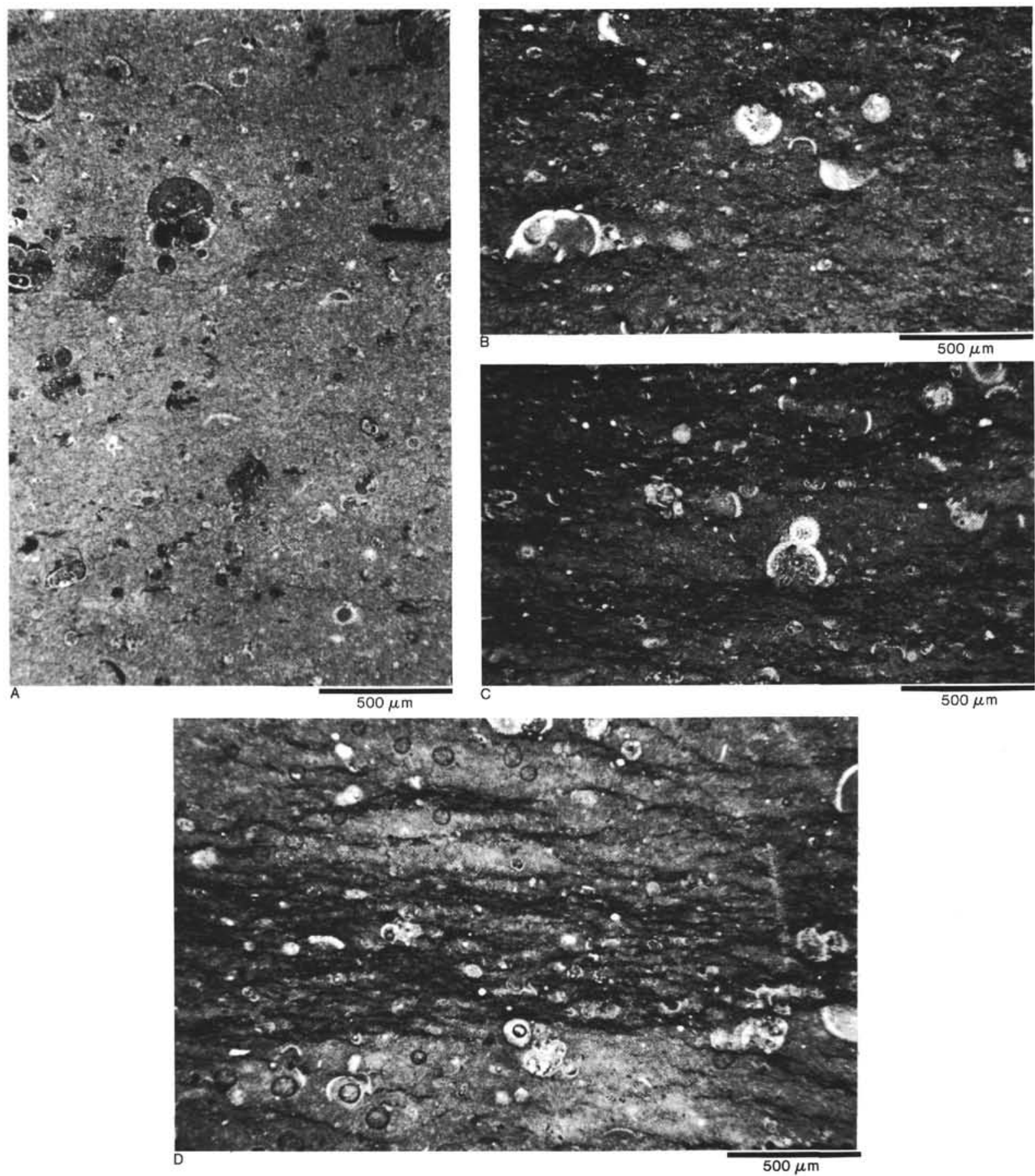

Figure 2. Thin-section micrographs. A. Undissolved chalk $(608-48-4,65 \mathrm{~cm})$. B. Beginnings of dissolution $(610-27-1,58 \mathrm{~cm})$. C. Anastomosing solution seams $(610-27-1,63 \mathrm{~cm})$. D. Merging solution seams, forming a discrete solution seam $(610-27-1,63 \mathrm{~cm})$. Note progressive dissolution of foraminifer tests and very fine-grained nature of solution seams.

tween the solution seams, and are truncated at the seams. The example shown in Figure 2D illustrates the very thin solution zones merging to form a wider band equivalent in scale to the wispy seams observed in hand specimen (Fig. 1B).

Examination by SEM showed that the chalk intervals are characterized by the presence of coccoliths and a very low $(<5 \%)$ content of clay and siliceous organisms (Fig. $3 \mathrm{~A})$. The coccoliths are variably preserved, showing both intense dissolution and later overgrowth (Fig. 3B). In contrast, the solution seams show very few preserved whole coccoliths; most are so badly dissolved that only their general outlines can be recognized. The solution seams are enriched in clay minerals, sponge spicules (Fig. 3C), diatoms, and radiolarian fragments. From area scan analyses using the energy-dispersive analyser, it is evident, however, that the solution seam zones are still dominated by calcium carbonate (i.e., they have proportionally high 

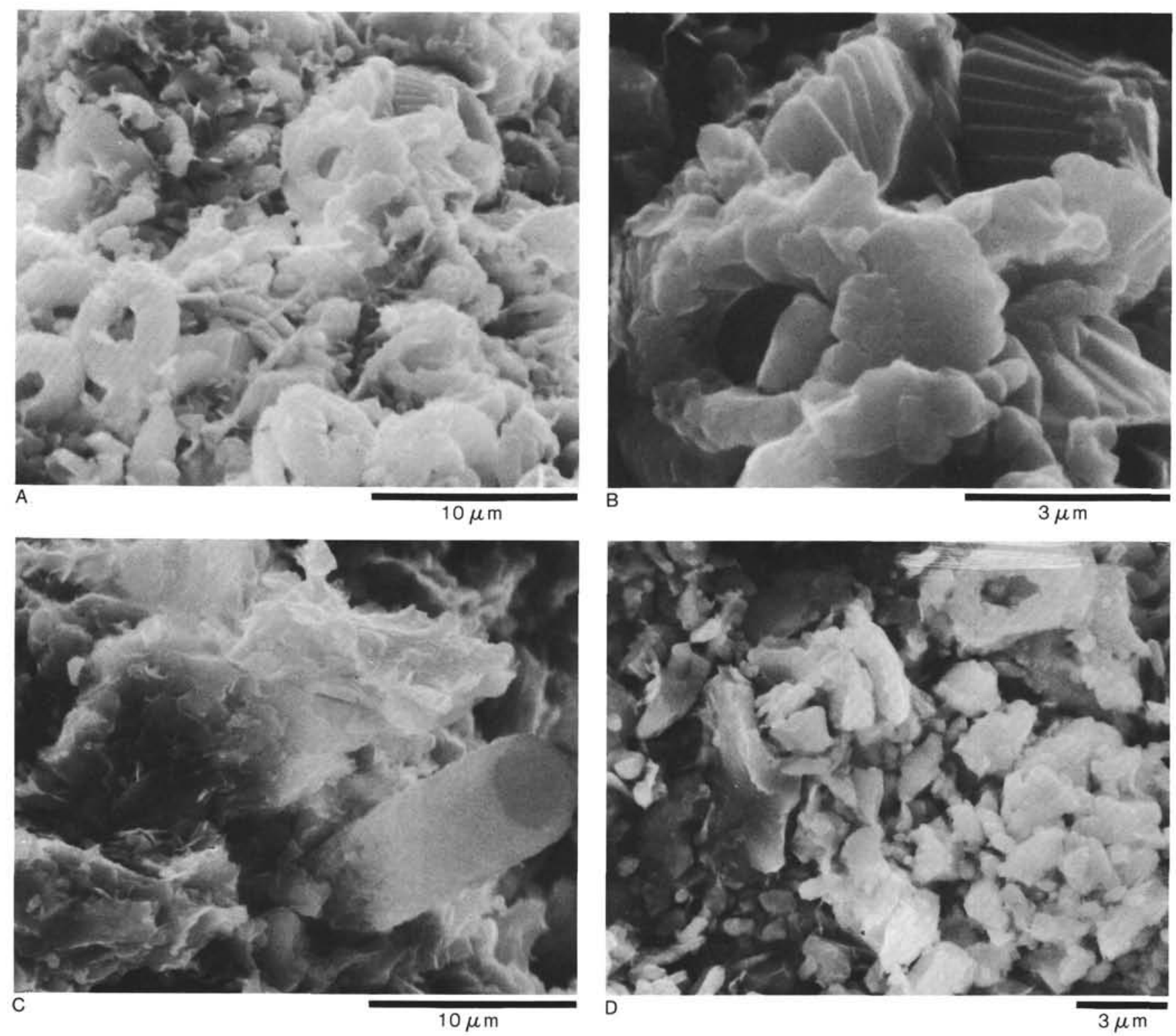

Figure 3. Scanning electron micrographs. A. Chalk lens showing relatively well preserved coccoliths $(\times 3070)$. B. Closer view of $(A)$ showing variable states of coccolith preservation $(\times 10,300)$. C. Solution seam showing clay mineral clusters and sponge spicule $(\times 3,070)$. D. Very finegrained carbonate grains in solution zone, and badly dissolved coccoliths $(\times 4700)$.

$\mathrm{Ca}$ content compared with $\mathrm{Si}$ and $\mathrm{Al}$ contents). The carbonate is present as very fine $(<2 \mu \mathrm{m})$ anhedral grains (Fig. 3D). Schlanger and Douglas (1974) have suggested that micrometer-sized carbonate is produced by the disaggregation of small coccoliths along sutures as a result of dissolution. Such a process seems highly probable in the examples discussed here.

\section{STRATIGRAPHIC SETTING OF SOLUTION FEATURES IN LEG 94 HOLES}

\section{Hole 608}

In Hole 608, there are two levels at which the structures are present: from 329 to $386 \mathrm{~m}$ sub-bottom (Cores 608-36 to 608-41) in the lower Miocene, and from 454 to $455 \mathrm{~m}$ (Core 608-49) in the upper Oligocene (Fig. 4). The sequence from 300 to $450 \mathrm{~m}$ sub-bottom in Hole 608 consists of alternating white and pale gray to pale brown chalk. Smear-slide estimates suggest that the pale gray and brown intervals are slightly more marly in composition. High-angle faults with a few millimeters displacement are common in the beds between the solution seams (Fig. 4). The fault planes are covered with very thin, dark green, shiny coatings of clay, which generally have slickenside surfaces. A chalk breccia unit, interpreted as a debris flow deposit, occurs at $370 \mathrm{~m}$ sub-bottom.

The chalk-marl alternations are most pronounced below $400 \mathrm{~m}$, and smear slides indicate a marly chalk composition. Bioturbation structures are clearly visible at the boundaries between chalk and marly beds, and individual burrow traces can be distinguished. Most burrows show a distinct flattening (Fig. 5), but the degree of flattening appears to be greater in some intervals than in others. The long axes of the deformed burrows usually lie at an angle to the horizontal. At the base of the marly sequence is a second thin sequence of solution fea- 

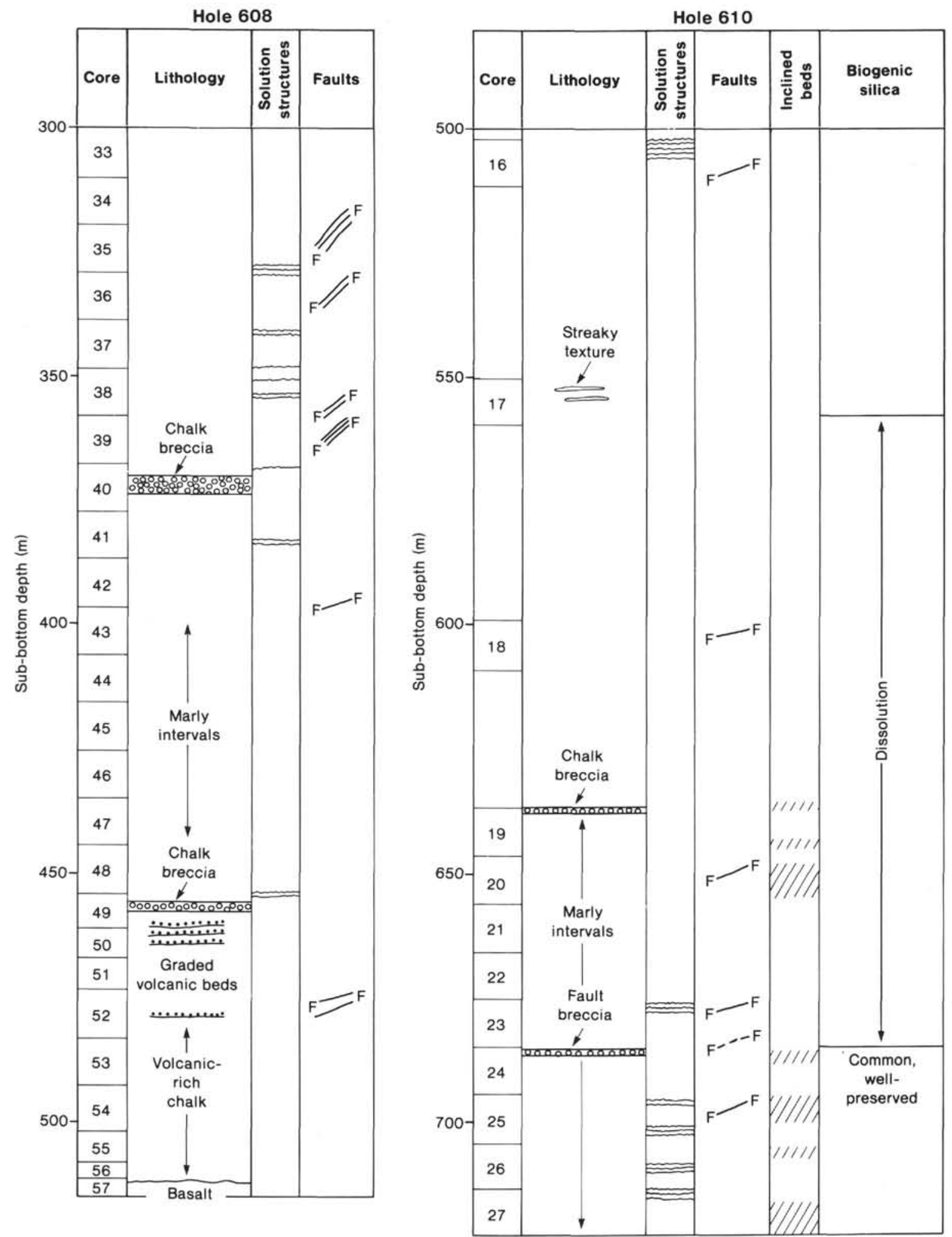

Figure 4. Synthesis of lithologic and post-depositional features of zones showing solution structures in Holes 608 and 610.

tures which overlies another chalk breccia bed at $450 \mathrm{~m}$ (Fig. 4). This breccia is also interpreted as a debris flow deposit, and is associated with a hiatus of about 9 m.y. (Site 608 report, this volume). Beneath this bed is a sequence of relatively silica-rich volcaniclastic beds, which shows further signs of faulting.
The interval containing the solution structures can be correlated with seismic Unit D on the air-gun seismic profiles (Fig. 6A). This unit is seismically transparent, with faint discontinuous reflectors. The measured seismic velocities in this interval show a regular but gradual increase downward (see Site 608 report, this volume). 


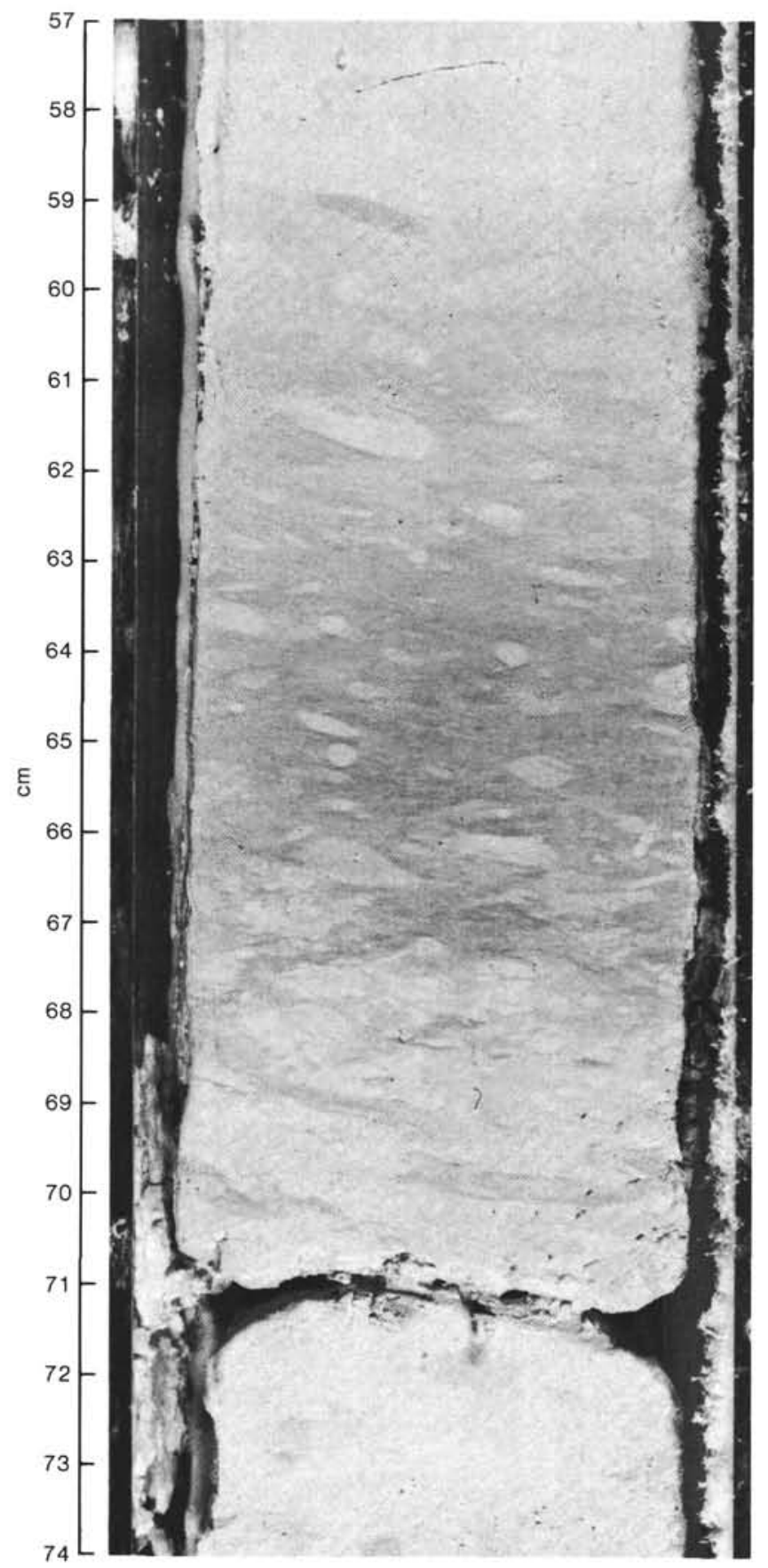

Figure 5. Marly interval in Hole 608, showing flattened burrows (608$48-4,57-74 \mathrm{~cm})$.

\section{Hole 610}

Solution structures were first observed in Hole 610 at a sub-bottom depth of $504 \mathrm{~m}$ (Section 610-16-1; Fig 4). The zone of solution is $4.5 \mathrm{~m}$ thick in this core, and $1.5 \mathrm{~m}$ below the lowest occurrence there is a fault, thought to have a throw of at least several centimeters because two distinct lithologies are present at the contact. Cores were recovered at 50 - $\mathrm{m}$ intervals through the middle Miocene, so that the extent of this solution zone is unknown. Part of Core 610-17 showed a distinctive "streaky" texture (Fig. 7), however, with burrows greatly elongated in the horizontal plane. Faulting occurs in Core 610-18 at $602 \mathrm{~m}$ sub-bottom.

Sampling was continuous below $640 \mathrm{~m}$, and the sequence becomes progressively more marly downward. The interval from Core 610-19 to Core 610-27 (636-723 m) is characterized by faulting and major tilting of the bedding, with dips of up to $45^{\circ}$ (Figs. 4 and 8 ). In the top of this sequence (Cores 610-19 to 610-24), the seismic velocity increased suddenly and the drilling penetration rate decreased (see Site 610 report, this volume). Solution structures occur from $675 \mathrm{~m}$ to the bottom of the hole (Cores 610-23 to 610-27), where the seismic velocity decreased and drilling penetration rates increased again. As at Site 608, faults occur in undissolved intervals between the solution structures. A further characteristic of this zone is the dissolution of siliceous microfossils, particularly diatoms, in Cores $610-17$ through $610-23$, and a downward increase in numbers and preservation from Core $610-24$, below $685 \mathrm{~m}$ sub-bottom (see Site 610 report, this volume).

The complex zone between 500 and $700 \mathrm{~m}$ sub-bottom corresponds to the diffuse zone of reflectors seen on seismic profiles (Fig. 6; Masson and Kidd, this volume), interpreted as corresponding to a regional reflector (R2). Although velocities are relatively high in Cores 610-19 to 610-24, reflectors within this interval are discontinuous, probably reflecting the faulted and tilted nature of the sediment sequence. The solution structures occur on both sides of the high-velocity interval.

\section{EXAMPLES FROM THE OTHER DSDP SITES}

A brief survey of Initial Reports volumes indicated that solution structures are common to chalk and limestone sequences cored in all major oceans. Table 1 summarizes the characteristics of the chalk sequences in which solution structures have been recorded. Considering that there has been no preselection of the data, the six sites listed in Table 1 show remarkable similarities to each other and to Sites 608 and 610 .

The solution structures correspond closely to zones on the seismic records where the reflectors are discontinuous and diffuse. The seismic units characteristically have considerable surface relief (up to $100 \mathrm{~m}$ ), which corresponds to even greater relief on the acoustic basement. The zones may be transparent or may show relatively high-amplitude reflections and be correlatable over long distances, but the internal reflectors maintain their discontinuous character over short distances. An exception to this is Site 534 on the Blake-Bahama Ridge, where the structures occur in a well-stratified sequence, according to the multichannel record (Sheridan, Gradstein, et al., 1983). The resolution of this profile, however, and averaging during processing, may have led to loss of detailed information on the zone.

At Site 516, the solution features occur at or immediately abové a seismic unit which Barker, Carlson, Johnson, et al. (1983) termed a "midsection dome" and which earlier workers had interpreted as basement. "The sequence has an irregular upper surface, a complicated internal structure, and a relatively flat base. It does not appear to be influenced by the underlying 'basement' to- 
pography, but the overlying reflectors are influenced by it, apparently undergoing differential compaction and faulting" (Barker, Carlson, Johnson, et al., 1983, p. 186). From the drilling results at this site, the shipboard party interpreted the "midsection domes" of the seismic profiles to be diagenetically related and controlled mainly by the availability of silica. The solution features occur just above an interval of rapid increases in sonic velocity and bulk density.

This association with intervals of increased density and sonic velocity is common to most of the sites for which information is available. Most authors referenced in Table 1 also indicate a measured decrease in porosity, and attribute the high-velocity zone to greater lithification and silica precipitation. At three sites, chert nodules were observed within $50 \mathrm{~m}$ of the solution seams. The solution seams at those sites generally surround the zones of silica precipitation, but apparently do not coincide with them.

\section{EXAMPLE FROM THE EUROPEAN CHALKS}

Garrison and Kennedy (1977) noted the presence of solution structures in several sequences of the Upper Cretaceous chalk of southern England. The Lower Chalk localities on the Isle of Wight in southern England, described by Garrison and Kennedy (1977), were visited by the author for comparison with the examples from DSDP holes described here. On the Isle of Wight, the solution structures occur throughout the Cenomanian-Campanian interval, but are most obvious in the CenomanianSantonian.

The character of the solution structures is macroscopically identical to the features described in this chapter for DSDP holes. On a microscopic scale, the Cretaceous chalk samples contain a more abundant coarse component, and often show deformation, as illustrated by Garrison and Kennedy (1977). The solution structures always lie parallel to bedding, in zones 10 to $20 \mathrm{~cm}$ thick irregularly spaced $50 \mathrm{~cm}$ to several meters apart (Fig. 9). As pointed out by Garrison and Kennedy (1977), the solution structures are more readily recognizable in marly intervals of the chalk.

On a fine scale, there is some evidence that lithology controls dissolution. In marl beds, the solution seams are generally diffuse (similar to type 1 described on the basis of DSDP cores), whereas more discrete seams are present in the chalkier burrow-fill within the same marl bed.

Several features analogous to the faulting associated with Leg 94 sequences are evident in the Isle of Wight rocks. One bed between solution structures was broken up by a set of small normal faults with offsets of a few centimeters (Fig. 10). Other beds commonly show parallel joint patterns, which cross the undissolved chalk beds at high angles to the solution seams and bedding planes but are deflected to lower angles at the bedding planes (Fig. 11). Some joints have a sigmoidal geometry and may cut across the solution seams at relatively low angles (Fig. 12), whereas, more commonly, other joints are wholly contained within the chalk beds.

\section{DISCUSSION}

\section{Solution as a Response to Stress}

The structures described in this chapter are common features of chalk sequences that have suffered a moderate amount of burial. They have been interpreted by Garrison and Kennedy (1977) and Scholle (1977) as resulting from pressure solution.

The role of pressure solution in carbonate diagenesis has been well established (Thompson, 1862; Wagner, 1913; Bathurst, 1976, chapter 11), and pressure solution is used to explain the presence of stylolites in many carbonate rocks. Wanless (1979) recognized "nonsutured seam solution," similar to the examples described here, in $\mathrm{Pa}$ leozoic limestones, and suggested that the solution is a response to deformation resulting from overburden or tectonic stress. Two lines of evidence from the chalk sequences described here support Wanless's interpretation and indicate that differential compaction subsidence is the likely cause of the stresses: (1) faulting and fracturing in resistant beds between solution seams indicate slip along bedding-planes; (2) intervals of dissolution in the DSDP holes overlie and are interbedded with large-scale zones of deformation related to differential compaction.

Faulting and fracturing were observed in DSDP Holes 608 and 610 and in the Isle of Wight chalks. The amount of displacement at the faults in Holes 608 and 610 is generally very small or difficult to determine, owing to the homogeneity of the lithology. Where displacement can be determined, the faults are always normal (Fig. 8). In the Isle of Wight chalks, small normal faults in the unaffected chalk beds (Fig. 10) and fracture lineations which turn into the solution seams (Figs. 11 and 12) indicate a stress field with a maximum principal stress directed normal to bedding and with a shear component parallel to bedding (Fig. 13). As suggested by Wanless (1979), the solution seams have accommodated shear parallel to bedding, whereas the more resistant chalk beds have deformed in a brittle fashion by faulting and fracturing. By analogy with the clearly observed features in the Isle of Wight outcrops, the same interpretation is suggested for solution seams in Holes 608 and 610.

The cause of subhorizontal shear is most probably adjustment resulting from differential compaction on a regional scale. The zones of diffuse, discontinuous reflectors at depth in the site survey seismic profiles correspond to disruption of the bedding by faulting and associated folding through discrete intervals of several meters in the drill holes. Mayer (1981) and Buckley and Grant (1985) have demonstrated that faulting develops in deepsea sediments as a response to differential compaction over high-relief basement topography. At Site 610, the faulted zones are in part equivalent to an interval of harder lithologies, as demonstrated by the decrease in drilling penetration rate. An interval with similar seismic character at Site 516 is related to a "front" of silica diagenesis and harder lithologies (Barker, Carlson, Johnson, et al., 1983).

Thus, the stresses generated by differential compaction are accommodated in harder lithologies by faulting. 


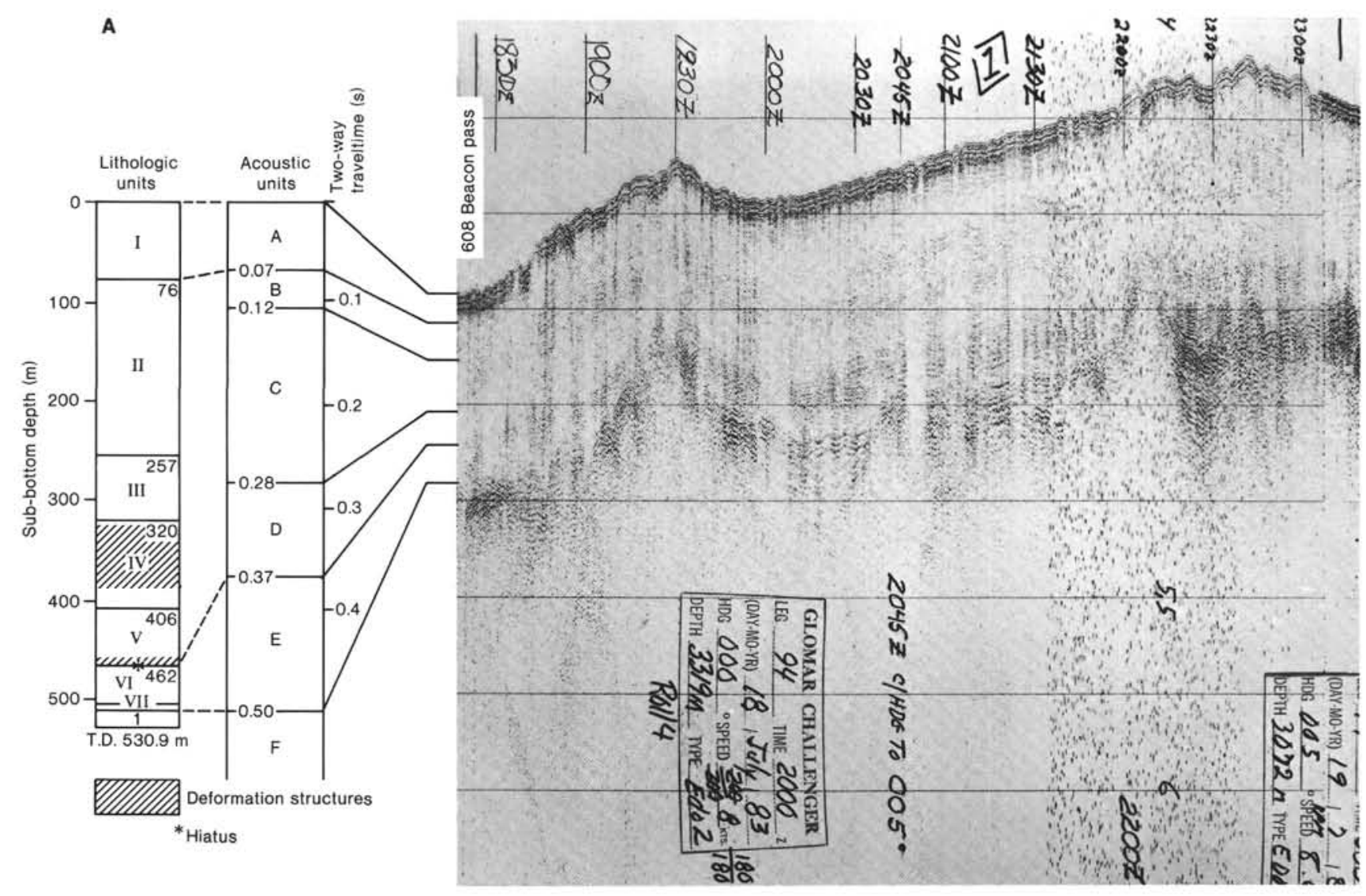

Figure 6. Correlation of solution structures with air-gun seismic profiles. A. Site 608. B. Site 610 .

This is apparent at both the bed scale and at larger scales. More ductile deformation takes place along softer beds, causing pressure solution and development of the solution seams. The evidence presented here therefore supports Wanless's (1979) general concept that non-sutured seam solution is a response to stress and is associated with lateral movement along the seam.

\section{Behavior on a Microscopic Scale}

The mechanism of deformation-related pressure solution can be better understood by considering the behavior of ooze and chalk at a grain-to-grain scale. Factors such as pore-water chemistry and groundwater circulation are important controls on dissolution, but the mechanical processes are thought to be most important in determining the style of the solution seams. The following discussion is therefore restricted to the mechanical processes which may result from shear deformation. Calcite in ooze and chalk is present predominantly as coccolith tests, which give the sediment a granular (rather than plastic) property (Nacci et al., 1975), resulting in mechanical behavior analogous to that of a silt with a low clay content. A second important property results from the fact that the porous, particulate microstructure of calcareous ooze is capable of storing intraparticle water. This water appears to be released at low strain levels $(3-4 \%)$ as the aged or partially cemented particulate structure is destroyed, resulting in maximum excess pore pressures at this strain level (Nacci et al., 1975).
As suggested by Neugebauer $(1973,1974)$, pressure solution is dependent on the contact pressure between two grains. In geotechnical terms, this pressure is known as the effective stress $\left(\sigma^{\prime}\right)$, which is related to the total stress $(\sigma)$ and pore fluid pressure $(u)$ by

$$
\sigma^{\prime}=\sigma-u
$$

(Terzaghi, 1936). Thus, the amount of pressure solution is largely dependent on the pore fluid pressure, Scholle (1977) related a lack of cementation and resultant high porosities in deeply buried Cretaceous chalks in the North Sea to the overpressured nature of the rocks at this level. High pore pressures reduce the effective stress or contact pressure on the grains and thus inhibit pressure solution. Conversely, reduced pore fluid pressure will increase the effective stress and allow pressure solution to take place.

During deformation of granular sediments, both increases and decreases in pore fluid pressure can take place. The behavior of sandy granular sediment under applied stress is highly dependent on (1) confining pressure, (2) the initial void ratio of the sediment (i.e., whether the sediment is loosely or densely packed), and (3) the drainage conditions. Little work has been done on the properties of oozes and chalks, but the few consolidation and triaxial tests completed on carbonate oozes (Nacci et al., 1973; Walton et al., 1983) show basically granular behavior. A loosely packed granular sediment will tend to show a decrease in volume with increased shear stress- 




Figure 6 (continued).

es, although slight dilation can occur at low effective stress values (Holtz and Kovacs, 1981, p. 498). Therefore, undrained loosely packed granular sediment will generally produce high pore fluid pressures under shearing. On the other hand, when a dense granular sediment is sheared, it has a tendency to decrease in volume initially, then expand (dilate) as particles are forced over each other (see Holtz and Kovacs, 1981, p. 496). Under undrained conditions, pore fluids will inhibit volume changes and pore fluid pressures will respond to the attempted volume changes by respectively increasing, then decreasing. Pressure solution is favored when the pore fluid pressure decreases in this fashion.

Extrapolating these geotechnical observations to chalks should be done only with great caution, because of the unusual nature of the particles, the significant degree of cementation possible even in the softest chalks, and the lack of information on the properties of chalks. A few tests on oozes suggest that the cementation affects the stress-strain properties at low strains. In one test shown by Nacci et al. (1973), very slight negative pore pressures were recorded.

The presence of clay in the chalk may reduce the permeability significantly and produce the undrained conditions required for pressure solution. Garrison and Kennedy (1977) observed the relationship between solution seams and the more marly intervals. As deformation and dissolution progresses, the coccolith plates are broken down into the very fine particles which are observed in the seams (Fig. 3D). This leads to a significant reduction in volume, and if intraparticle water is present the water is released. With the clay still preventing drainage, high pore-water pressures result and decrease the potential for dissolution.

As a result of the foregoing processes, the conditions for pressure solution are short-lived along individual seams. The high pore pressures may allow continued deformation along the seam with little extra dissolution. Thickening of solution seams occurs primarily as a mechanical convergence of numerous very thin seams, rather than by means of continued dissolution along the individual seams.

\section{CONCLUSIONS}

Evidence presented here supports the suggestion that solution structures observed in chalks from DSDP sites and from land sequences may be related to mechanical deformation, perhaps resulting from differential compaction over basement highs. Pore fluid pressures and the granular behavior of oozes and chalks play a significant role in controlling pressure solution during mechanical deformation, and can explain the development of seam-type solution features.

\section{ACKNOWLEDGMENTS}

Much of this work was carried out while the author was visiting the Grant Institute of Geology, University of Edinburgh. I thank Professor G. Y. Craig and Dr. D. Stow for their hospitality. The work was supported in part by a grant from the Nuffield Foundation to Dorrik Stow. Thanks also to Doug Gillies and Patricia Stoffyn-Egli for assistance with microscopic and SEM work, and to Lindsay Parson, Phil 


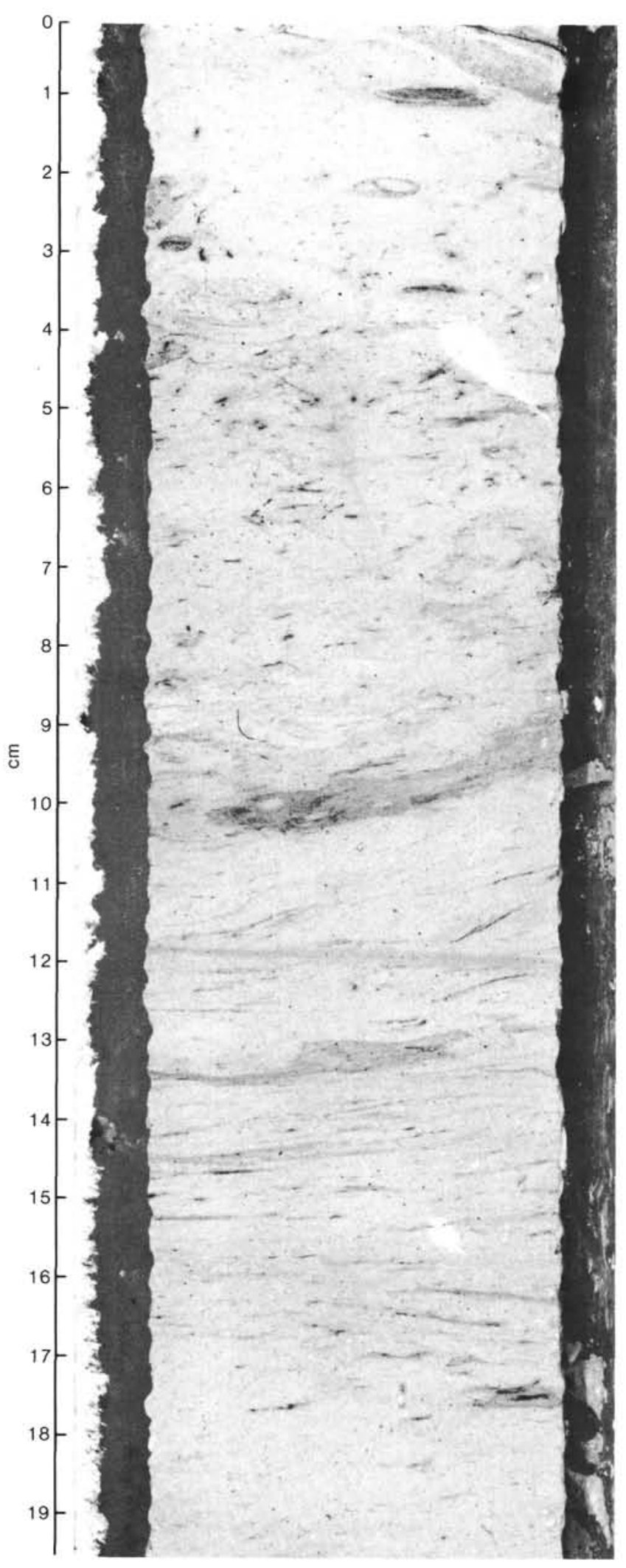

Figure 7. "Streaky" texture in Sample 610-17-1, 0-20 cm.



Figure 8. Inclined bedding and microfaulting in Sample 610-24-2, 90$100 \mathrm{~cm}$.

Weaver, and Quentin Huggett for stimulating discussions in the field. The manuscript has benefited from reviews by L. Parson, L. Jansa, K. Moran, W. J. Kennedy, and J. P. A. Noble.

\section{REFERENCES}

Andrews, J. E., Packham, G., et al., 1975. Init. Repts. DSDP, 30: Washington (U.S. Govt. Printing Office).

Barker, P. F., Carlson, R. L., Johnson, D. A., et al., 1983. Init. Repts. DSDP, 72: Washington (U.S. Govt. Printing Office).

Bathurst, R. G. C., 1976. Carbonate Sediments and Their Diagenesis: New York (Elsevier).

Buckley, D. E., and Grant, A. C., 1985. Fault-like features in abyssal plain sediments. J. Geophys. Res., 90:9173-9180.

Garrison, R. E., and Kennedy, W. J., 1977. Origin of solution seams and flaser structure in Upper Cretaceous chalks of southern England. Sed. Geol., 19:107-137.

Holtz, R. D., and Kovacs, W. D., 1981. An Introduction to Geotechnical Engineering: Englewood Cliffs, N. J. (Prentice Hall).

Mayer, L., 1981. Erosional troughs in deep sea carbonates and their relationship to basement structure. Mar. Geol., 39:59-80.

Nacci, V. A., Kelly, W. E., Wang, M. C., and Demars, K. R., 1973. Strength and stress-strain characteristics of cemented deep-sea sediments. In Inderbitzen, A. L. (Ed.), Deep Sea Sediments: Physical and Mechanical Properties: New York (Plenum Press), pp. 129-150.

Nacci, V. A., Wang, M. C., and Demars, K. R., 1975. Engineering behavior of calcareous soils. Proc. Conf. Civil Engineering in the Oceans (Newark, Delaware), Vol. 3: New York (Am. Soc. Civil Engineers), 380-400.

Neugebauer, J., 1973. The diagenetic problem of chalk. The role of pressure solution and pore fluid. Neues. Jahrb. Paläontol. Abh. 143:223-245. 
1974. Some aspects of cementation in chalks. In Hsü, K. J., and Jenkyns, H. C. (Eds.), Pelagic Sediments: On Land and Under the Sea. Int. Assoc. Sedimentol. Spec. Publ., 1:149-176.

Schlanger, S. O., and Douglas, R. G., 1974. The pelagic ooze-chalklimestone transition and its implications for marine stratigraphy. In Hsü, K. J., and Jenkyns, H. C. (Eds.), Pelagic Sediments: On Land and Under the Sea. Int. Assoc. Sedimentol. Spec. Publ., 1: 117-148.

Scholle, P. A., 1977. Chalk diagenesis and its relation to petroleum exploration: Oil from chalks, a modern miracle? Am. Assoc. Pet. Geol. Bull., 61:982-1009.

Sheridan, R. E., Gradstein, F. M., et al., 1983. Init. Repts. DSDP, 76: Washington (U.S. Govt. Printing Office).

Terzaghi, K., 1936. Relation between soil mechanics and foundation engineering. Proc. First. Int. Conf. Soil Mechanics and Foundation Engineering, Vol. 3: Cambridge, Mass. (Graduate School of Engineering, Harvard University), 13-18.
Thompson, J., 1862. On crystallization and liquefaction, as influenced by stresses tending to change of form in crystals. Phil. Mag., 24: 395-401.

von der Borch, C. C., Sclater, J. G., et al., 1974. Init. Repts. DSDP, 22: Washington (U.S. Govt. Printing Office).

Wagner, G., 1913. Stylolithen and Drucksuturen. Geol. Palaeontol. Abhandl. (N. F.), 11:101-128.

Walton, W. H., Sangrey, D. A., and Miller, S. A., 1983. Geotechnical engineering characterization of hydraulically piston-cored deep ocean sediments. In Barker, P. F., Carlson, R. L., Johnson, D. A., et al., Init. Repts. DSDP, 72: Washington (U.S. Govt. Printing Office), 537-549.

Wanless, H. R., 1979. Limestone response to stress: Pressure solution and dolomitization. J. Sedimentol. Petrol., 49:437-462.

Whitmarsh, R. B., Weser, O. E., Ross, D. A., et al., 1974. Init. Repts. $D S D P, 23$ : Washington (U.S. Govt. Printing Office).

Table 1. Site information of DSDP holes that have penetrated chalk solution structures.

\begin{tabular}{|c|c|c|c|c|c|c|}
\hline Site & Location & $\begin{array}{l}\text { Sub-bottom } \\
\text { depth }(\mathrm{m})\end{array}$ & $\begin{array}{l}\text { Age of intervals } \\
\text { containing } \\
\text { solution seams }\end{array}$ & Seismic setting & Stratigraphic association & Physical properties \\
\hline 216 & $\begin{array}{l}\text { Ninety-east Ridge, } \\
\text { Indian Ocean }\end{array}$ & 335 & late Maestrichtian & $\begin{array}{l}\text { Transparent to diffusely } \\
\text { stratified sequence } \\
\text { overlying basement } \\
\text { ridge }\end{array}$ & $\begin{array}{l}\text { At Cretaceous/Tertiary } \\
\text { boundary }-2 \text {-m.y. hiatus. } \\
30 \mathrm{~m} \text { below chert nodules } \\
\text { and }<10 \mathrm{~m} \text { above } \\
\text { glauconitic foraminiferal } \\
\text { clay }\end{array}$ & - \\
\hline 223 & $\begin{array}{c}\text { Base of Owen Ridge, } \\
\text { Arabian Sea }\end{array}$ & 490 & early Miocene & $\begin{array}{l}\text { At disconformity be- } \\
\text { tween ponded, } \\
\text { stratified sequence } \\
\text { above and dipping } \\
\text { (?draped) transparent } \\
\text { layer beneath }\end{array}$ & $\begin{array}{l}1 \mathrm{~m} \text { above hiatus, } 4 \mathrm{~m} \text { below } \\
\text { chalk breccia }\end{array}$ & $\begin{array}{l}<10 \mathrm{~m} \text { above high- } \\
\text { density and } \\
\text { high-velocity } \\
\text { zone }\end{array}$ \\
\hline 288 & $\begin{array}{l}\text { Base of Ontong-Java } \\
\text { Plateau }\end{array}$ & 750 & late Coniacian & $\begin{array}{l}\text { Lower flanks of Plateau. } \\
\text { Diffuse zone of high } \\
\text { amplitude reflectors. }\end{array}$ & $\begin{array}{l}\text { Within apparently continuous } \\
\text { sequence, } 50 \mathrm{~m} \text { below } \\
\text { hiatus. Associated with } \\
\text { extensive chert develop- } \\
\text { ment. }\end{array}$ & $\begin{array}{l}\text { Just below zone of } \\
\text { increased sonic } \\
\text { velocity and } \\
\text { reduced porosity }\end{array}$ \\
\hline 289 & Ontong-Java Plateau & 930 & early Oligocene & $\begin{array}{l}\text { Diffuse zone of high- } \\
\text { amplitude reflections } \\
\text { just below very well } \\
\text { stratified sequence }\end{array}$ & $\begin{array}{l}\text { 30-40 m above hiatus. } \\
\text { Above, and associated } \\
\text { with, extensive chert } \\
\text { nodule development. }\end{array}$ & $\begin{array}{l}\text { In lower part of } \\
\text { increased- } \\
\text { velocity zone }\end{array}$ \\
\hline 516 & Rio Grande Rise & 580 & late Eocene & $\begin{array}{l}\text { Transparent to diffusely } \\
\text { stratified sequence } \\
\text { immediately overlying } \\
\text { "midsection domes" } \\
\text { (interpreted as } \\
\text { diagenetic front) }\end{array}$ & $\begin{array}{l}\text { Within continuous sequence } \\
\text { (no hiatuses) }\end{array}$ & $\begin{array}{l}20 \mathrm{~m} \text { above rapid } \\
\text { increase in sonic } \\
\text { velocity and } \\
\text { bulk density }\end{array}$ \\
\hline 534 & Blake-Bahama Basin & 1270 & late Berriasian & $\begin{array}{l}\text { Well-stratified (on } \\
\text { multichannel record) }\end{array}$ & $\begin{array}{l}\text { Within continuous sequence } \\
\text { (no hiatuses) }\end{array}$ & $\begin{array}{l}\text { Zone of uniform } \\
\text { sonic velocity } \\
\text { overlying zone } \\
\text { of more variable } \\
\text { velocity }\end{array}$ \\
\hline
\end{tabular}

Note: From von der Borch, Sclater, et al. (1974); Whitmarsh, Weser, Ross, et al. (1974); Andrews, Packham, et al. (1975); Barker, Carlson, Johnson, et al. (1983); Sheridan, Gradstein, et al. (1983). 


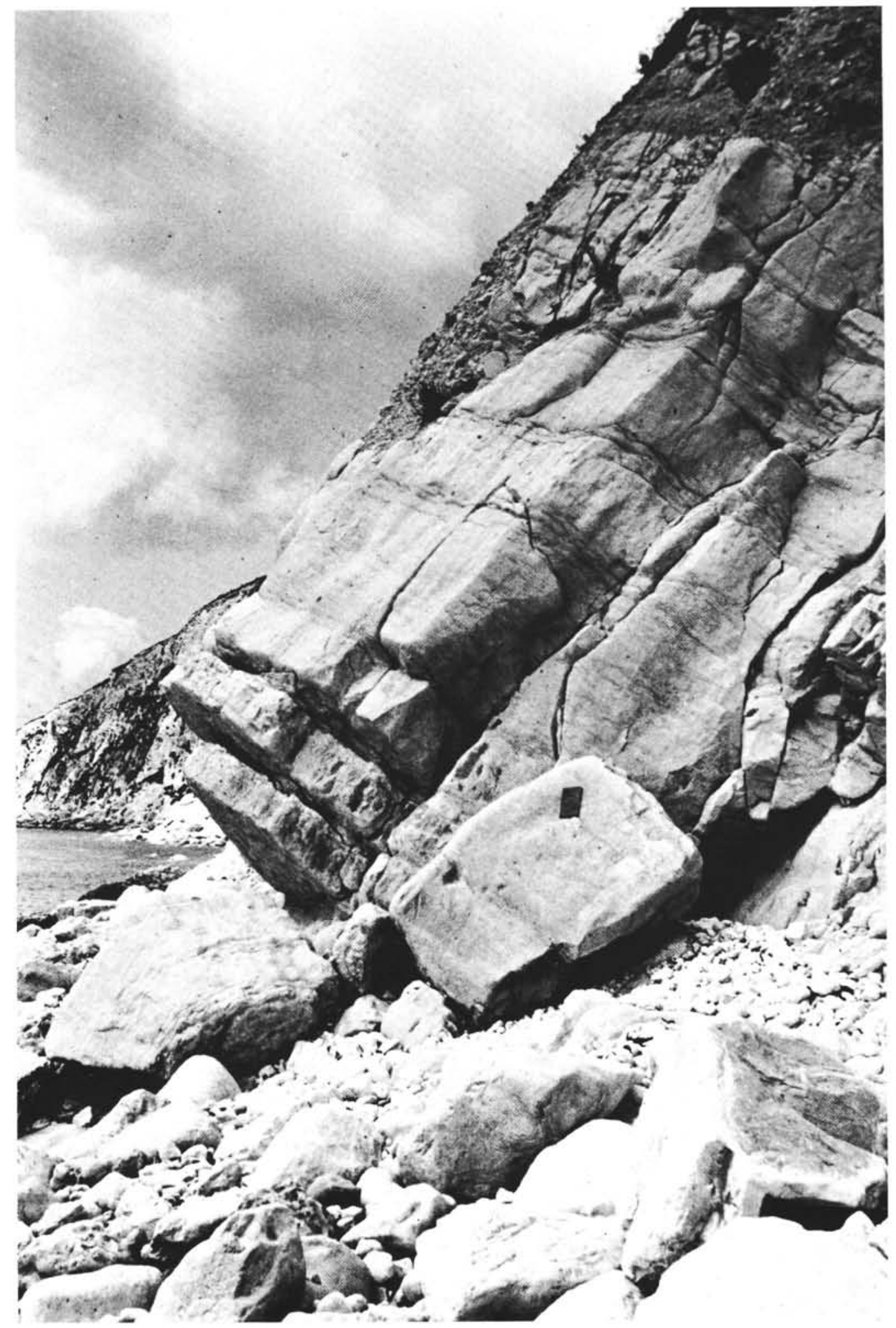

Figure 9. Solution zones in Upper Cretaceous chalk, Compton Bay, Isle of Wight. 


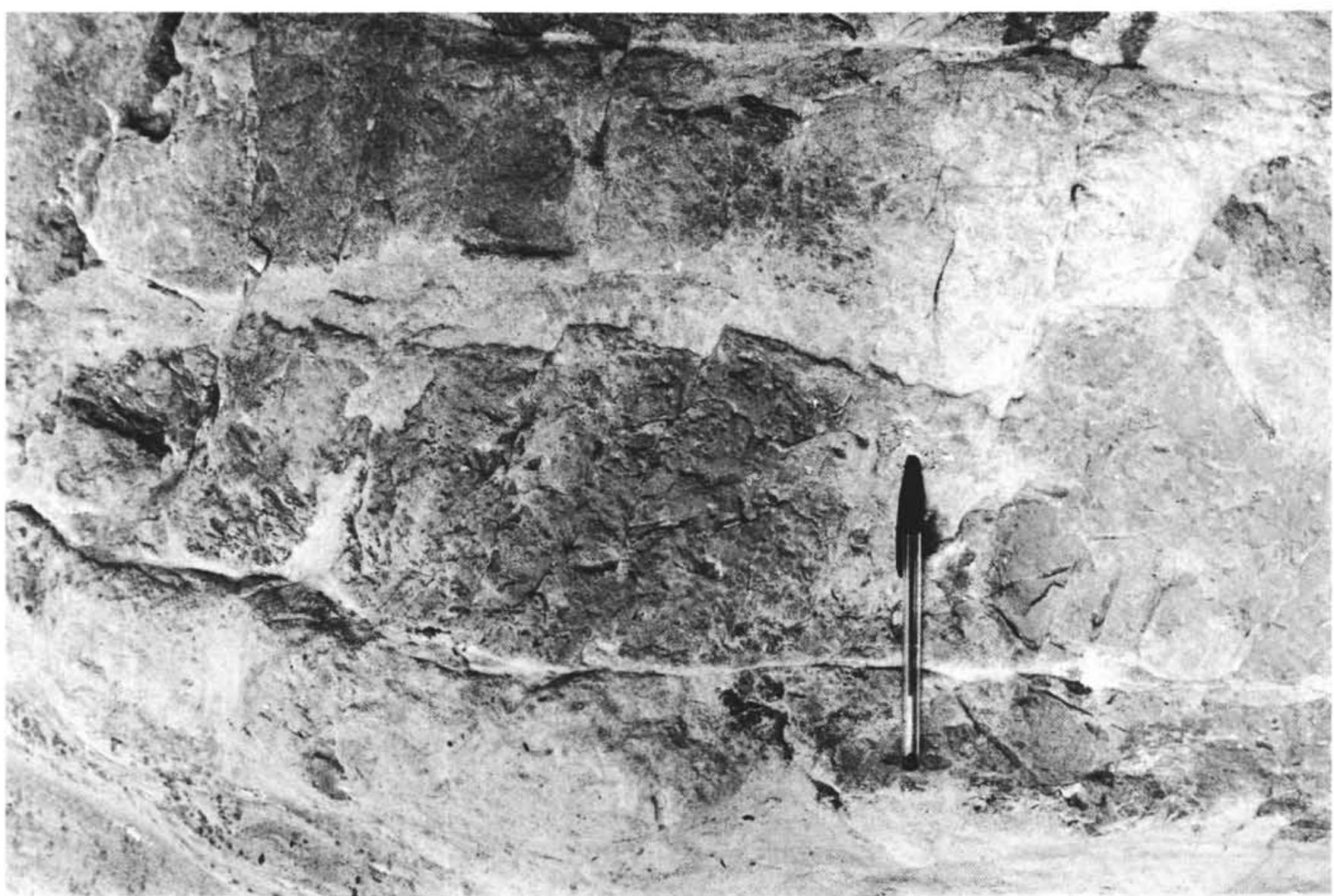

Figure 10. Microfaulted chalk bed, Compton Bay, Isle of Wight. 


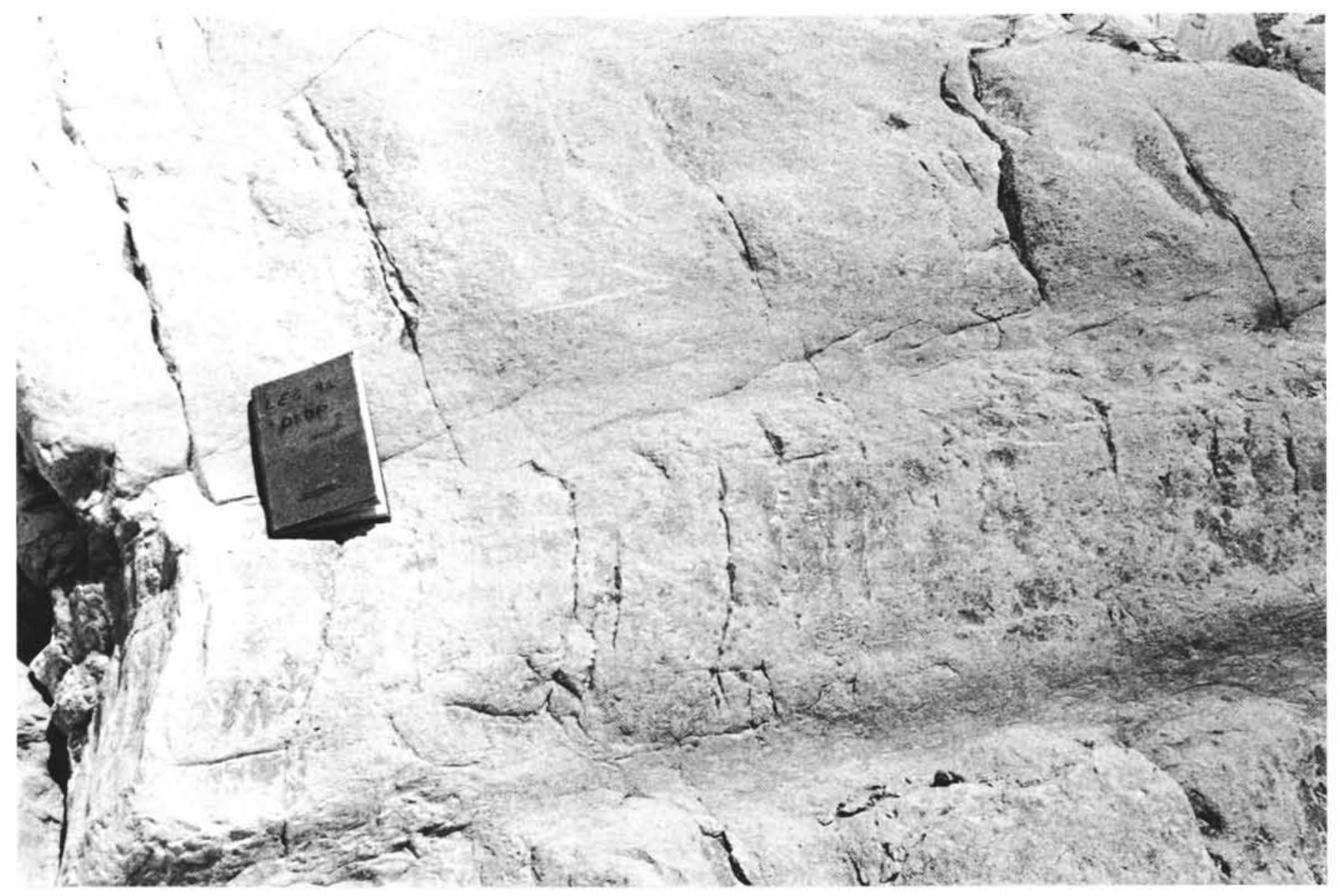

Figure 11. Jointing in chalk beds, Compton Bay, Isle of Wight. Note that the joint trace is deflected at the bedding planes. 


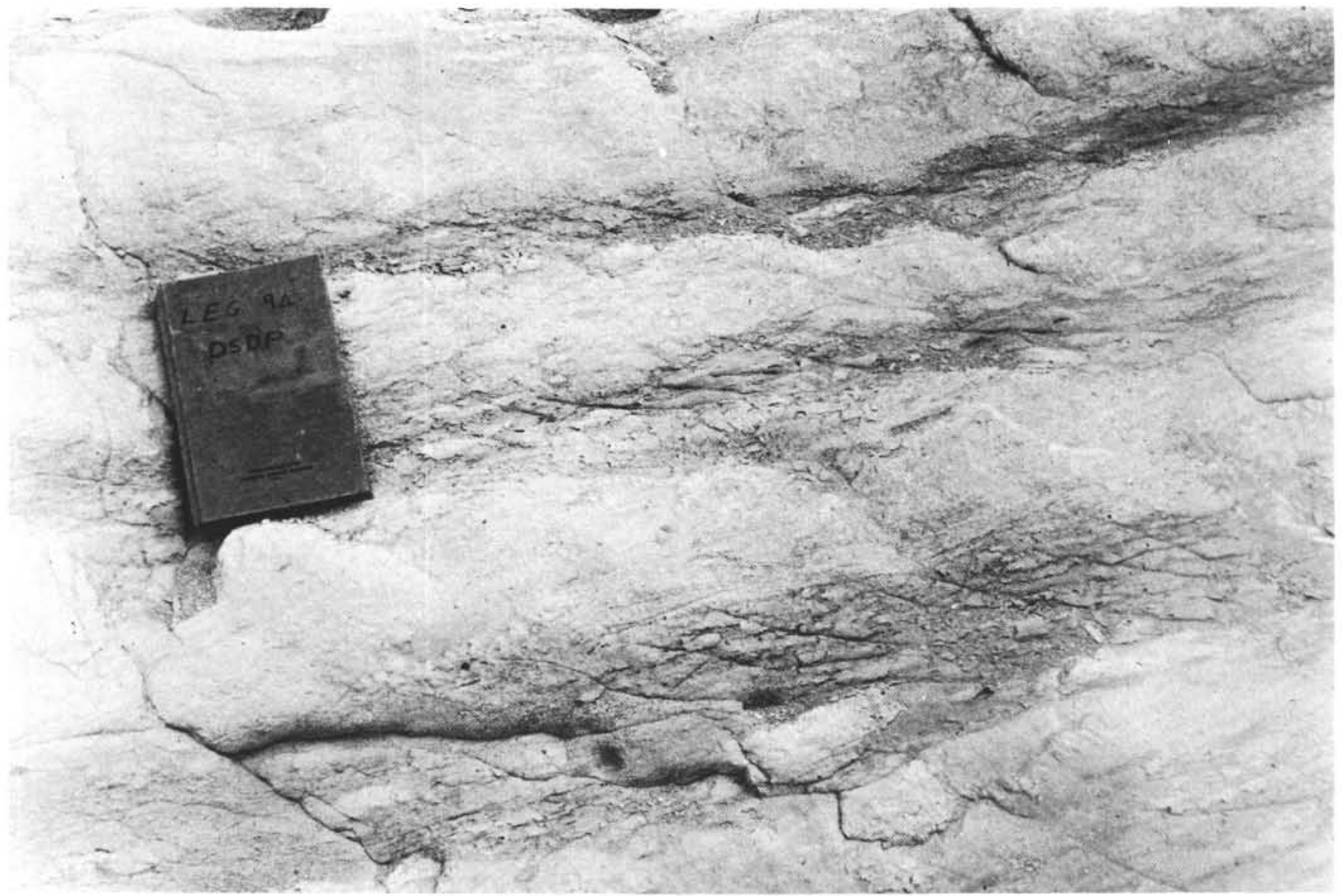

Figure 12. Sigmoidal joints crosscutting solution seams at low angle to bedding.

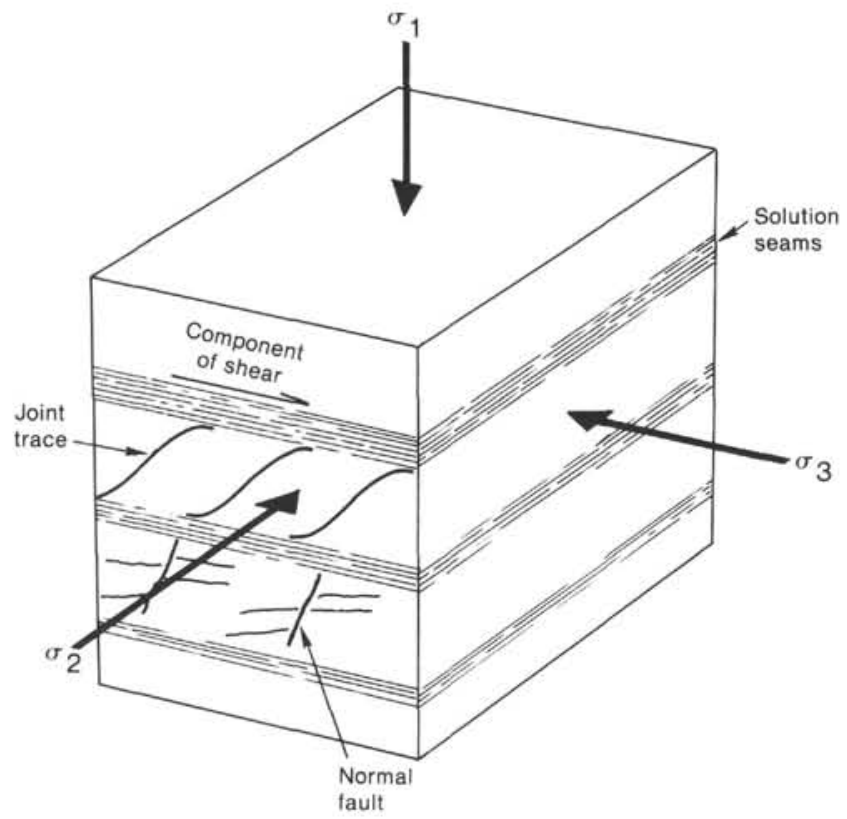

Figure 13. Directions of principal stress components inferred from the relationships between solution seams, microfaulting, and fractures in chalk beds from the Isle of Wight section: $\sigma_{1}>\sigma_{2}>\sigma_{3}$. 